\title{
Self-Esteem as Manipulative Status Communication
}

Victoria Blinkhorn ${ }^{1}$

(1)School of Psychology, University of Liverpool, Liverpool, UK

\section{Without Abstract}

\section{Synonyms}

Confidence; Dignity; Personal value; Pride; Self-regard; Self-worth

\section{Definition}

Self-esteem is a widely used concept in psychology and has been defined in numerous ways. Selfesteem can be described as an individual's overall sense of self-worth or personal value. It is generally accepted that self-esteem is the evaluative component of the self-concept. The self-concept is an extensive representation of the self that also includes cognitive and behavioral characteristics (Blascovich and Tomaka 1991). Within psychological research, self-esteem has been linked to a variety of domains, from personality, clinical, and behavioral concepts to eating disorders, aggression, and criminality. Almost all psychology theory refers to self-esteem, and as such, it is widely agreed that the need to maintain and enhance self-esteem is central to human behavior (Leary et al. 1995).

\section{Introduction}

This entry focuses on three key evolutionary perspectives of self-esteem; sociometer theory, ethological perspective, and terror management theory. Each perspective will be discussed in relation to how they present the function of self-esteem and how this may contribute to an individual's manipulative communication with others.

\section{Sociometer Theory}

Many theories have difficulties when attempting to fully explain the purpose of self-esteem.

Sociometer theory was offered as a new perspective, in order to help answer the questions other theories found problematic. Sociometer theory was developed by Leary et al. ( $\underline{1995}$ ) who proposed that self-esteem is an adaptation in the form of a gauge that monitors interactions an individual has with others. This gauge sends signals to the individual informing them as to how socially acceptable their behaviors are. According to this theory, all humans have an innate desire to have interpersonal relationships and to maintain these in a productive way. The desire for interpersonal relationships has been evolving since the beginning of the human species, as those who were part of formed groups had the highest chances of survival and, subsequently, reproduction. Individuals have evolved to have the 
ability to sense signals from this psychological gauge which alerts them to how much they are accepted or rejected by others and how well their overall behavior is aiding their integration into society (Anthony et al. 2007). The importance of an individual's relationship with others is often dependant on the reactions they receive from them. The sociometer is very sensitive to even the slightest change in these perceptions, and as such, when an individual's behavior is initiating a decrease in their evaluation, the sociometer makes them aware that there is a threat to their social acceptance, which then drives them to confront the problem. According to Leary et al. ( 1995), there are two variations of self-esteem: state self-esteem and trait self-esteem. State self-esteem refers to the perception of changes in an individual's level of social inclusion, given a particular setting. Selfesteem increases or decreases based on positive or negative feedback. Trait self-esteem refers to an individual's accumulated lifelong perception of social inclusion and exclusion. This is sometimes considered the resting position for the sociometer as this is how an individual feels when interpersonal information is absent (Leary et al. 1995).

Sociometer theory explains much human behavior and addresses important questions concerning selfesteem (Anthony et al. 2007). A common belief is that self-esteem is to be maintained or increased; however, the sociometer theory explains that its exact function is to reduce the chances of social rejection (Leary et al. 1995). Research has suggested that low self-esteem is related to a variety of issues such as academic failure, substance abuse, depression, anxiety, and criminal behavior; however, according to Leary et al. ( $\underline{1995})$, these relationships are typically overemphasized. From the perspective of the sociometer theory, these issues are actually due to low interpersonal evaluations and sometimes social rejection. In other words, low self-esteem is not the cause of these issues, but rather, levels of self-esteem and the psychological behavioral problems co-occur. When this happens, further issues may develop and maladaptive behaviors become more common.

As sociometers monitor individuals' current standing in order to guide them toward adaptive strategic choices, it could be expected that they are designed to do this accurately. However, interestingly, there is a substantial amount of literature suggesting that most individuals have modestly inflated views of themselves and, as a result, display a variety of "positive illusions" (Taylor and Brown 1988). Krebs and Denton (1997) explain that positive illusions to in-group and out-group biases reflect the adaptive design of these cognitive systems rather than malfunctions. In other words, sociometers may be regulated by an adaptive, built-in, positive bias. This may have implications on the behavior of individuals, specifically when interacting with others. As an individual's value or current standing in interpersonal environments is the function of how others evaluate them, the main way to increase their value could be to deceive others using manipulative communication. However, the effectiveness of impression management strategies is limited when the individual is not convinced of their levels of worth they are promoting to others, as all humans are skilled at detecting this form of deception in self-presentation (Zahavi and Zahavi 1997). "Positive illusions" may therefore denote a form of selfdeception designed to increase the effectiveness of an individual's attempt to convince others to overvalue them, primarily due to their built-in positive bias or, in other words, because they believe in the level of worth they present (Kirkpatrick and Ellis 2003).

\section{Ethological Theory}

Ethology regards the adaptive value of behavior and its evolutionary history. The origins of ethology can be traced back to Darwin, the very first ethologist. His key belief was that behavioral traits are part of organisms' evolved phenotypes. During the 1960s, its application to research began; however, it has become more influential in recent years. 
In relation to self-esteem, the ethological perspective proposes that it is an adaptation that has evolved in order to maintain dominance in relationships (Barkow 1980). According to this theory, human beings have evolved specific mechanisms to monitor dominance, as this is what facilitated the attainment of a mate. Favorable reactions and attention from others were associated with being dominant; thus, feelings of self-esteem became attached to social approval and respect. From this perspective, the motive an individual has to enhance themselves positively, in evolutionary terms, is to enhance their relative dominance (Leary 1999). As this perspective deems an individual's dominance as crucially important in order to form relationships and reproduce, it's probable that humans will do anything they can to maintain this dominance. This could include using forms of manipulative communication such as telling lies, blackmailing, cheating, and seducing. More specific forms of this will be discussed in the following two short chapters, "Projected Confidence" and "Derogation of Rivals."

\section{Terror Management Theory}

Terror management theory is based on the writings of Becker (e.g., 1962) and Rank (e.g., 1941) and proposes that human beings continuously seek out ways to improve their self-esteem in order to protect them from the fear of death (Greenberg et al. 1986). According to this theory, the fear of death creates an instinct for self-preservation, just like other species. However, despite it being the same instinct, only humans are conscious that eventual death is unavoidable, and therefore, the selfpreservation instinct will inevitably fail. This combination of an instinctive drive for self-preservation and the knowledge that eventual death is unavoidable can create debilitating terror (Harmon-Jones et al. 1997). The possibility of experiencing this terror is managed by a cultural anxiety buffer consisting of the cultural worldview and self-esteem. "The cultural worldview is defined as a set of beliefs about the nature of reality shared by groups of individuals that provides meaning, order, permanence, stability, and the promise of literal and/or symbolic immortality to those who live up to the standards of value set by the worldview" (Harmon-Jones et al. 1997, p. 24). Due to the cultural anxiety buffer being a social creation, humans are dependent on others to validate and maintain it. As a result, the terror management theory proposes that a large percentage of behavior, both on an individual and social level, is specifically carried out to protect the cultural worldview and self-esteem.

Similar to the other theories already discussed, within the terror management theory, self-esteem provides protection against anxiety. Therefore, the higher the self-esteem one has, the less prone they are to experience anxiety and thus display anxiety-related behaviors. For example, various studies have demonstrated that the higher the self-esteem one has, the less they are to experience death anxiety (e.g., Templer 1971). In addition, any threats which may reduce self-esteem may cause one to behave defensively in response, for example, making excuses (Mehlman and Snyder 1985) and egodefensive attributions (Gollwitzer et al. 1982). This behavior would involve one manipulating others in order to enhance their perceived social value and, as a result, protect their anxiety buffer.

\section{Conclusion}

It is clear that the three key evolutionary perspectives of self-esteem discussed above share common themes in terms of the functions of self-esteem. Firstly, they are all concerned with protecting and preserving self-esteem. The reasoning behind this differs with each theory; however, the general principle is the same that self-esteem is important in order for individuals to live a fruitful life. 
Secondly, due to this importance, when their levels of self-esteem are threatened in any way, individuals will behave, sometimes undesirably, in order to protect it. As a result, various forms of manipulative communication with others can occur such as deception, telling lies, blackmail, and cheating, in order to maintain their perceived social value and self-esteem. In the next two short chapters, there will be a discussion into how individuals may manipulate others in specific ways, by "Projected Confidence" and the "Derogation of Rivals" and how specific personality constructs may accentuate this.

\section{Cross-References}

Derogation of Rivals

Projected Confidence

Self-Esteem Reflects Assessments of Valuation

Sociometer Theory

\section{References}

Anthony, D. B., Wood, J. V., \& Holmes, J. G. (2007). Testing sociometer theory: Self-esteem and the importance of acceptance for social decision-making. Journal of Experimental Social Psychology, 43, 425-432.

CrossRef

Barkow, J. (1980). Prestige and self-esteem: A biosocial interpretation. In D. R. Omark, F. F. Strayer, \& D. G. Freedman (Eds.), Dominance relations: An ethological view of human conflict and social interaction (pp. 319-332). New York: Garland STPM Press.

Becker, E. (1962). The birth and death of meaning. New York: Free Press.

Blascovich, J., \& Tomaka, J. (1991). Measures of self-esteem. In J. P. Robinson, P. R. Shaver, \& L. S. Wrightsman (Eds.), Measures of personality and social psychological attitudes (pp. 115-160). San Diego: Academic.

CrossRef

Gollwitzer, P. M., Earle, W. B., \& Stephan, W. G. (1982). Affect as a determinant of egotism: Residual excitation and performance attributions. Journal of Personality and Social Psychology, 43, 702-709.

CrossRef 
Greenberg, J., Pyszczynski, T., \& Solomon, S. (1986). The causes and consequences of the need for self-esteem: A terror management theory. In R. E. Baumeister (Ed.), Public self and private self (pp. 189-212). New York: Springer.

CrossRef

Harmon-Jones, E., Simon, L., Greenburg, J., Solomon, S., Pyszczynski, T., \& McGregor, H. (1997). Terror management theory and self-esteem: Evidence that increased self-esteem reduces mortality salience effects. Journal of Personality and Social Psychology, 72, 24-36.

CrossRef PubMed

Kirkpatrick, L. A., \& Ellis, B. J. (2003). An evolutionary-psychological approach to self-esteem: Multiple domains and multiple functions. In G. J. O. Fletcher \& M. S. Clark (Eds.), Blackwell handbook of social psychology: Interpersonal processes. Oxford: Blackwell.

Krebs, D. L., \& Denton, K. (1997). Social illusions and self-deception: The evolution of biases in person perception. In J. A. Simpson \& W. S. Rhodes (Eds.), Evolutionary social psychology (pp. 2147). Mahwah: Erlbaum.

Leary, M. R. (1999). Making sense of self-esteem. Current Directions in Psychological Science, 8 , 32-35.

CrossRef

Leary, M. R., Tambor, E. S., Terdal, S. K., \& Downs, D. L. (1995). Self-esteem as an interpersonal monitor: The sociometer hypothesis. Journal of Personality and Social Psychology, 68, 518-530. CrossRef

Mehlman, R. C., \& Snyder, C. R. (1985). Excuse theory: A test of the self-protective role of attributions. Journal of Personality and Social Psychology, 49, 994-1001.

CrossRef

Rank, O. (1941). Beyond psychology. New York: Dover.

Taylor, S. E., \& Brown, J. D. (1988). Illusion and well-being: A social psychological perspective on mental health. Psychological Bulletin, 103, 193-210.

CrossRef PubMed

Templer, D. I. (1971). The relationship between verbalized and nonverbalized death anxiety. Journal of Genetic Psychology, 119, 211-214. 


\section{CrossRef PubMed}

Zahavi, A., \& Zahavi, A. (1997). The handicap principle. New York: Oxford University Press. 